\begin{tabular}{|l|l|l|l|}
\hline - & Received 17/07/2019 & 喝 & Published 16/10/2019 \\
\hline
\end{tabular}

\title{
Accountability of Performance Integrated With the Value of Islamic Civilization: The Case of Muhammadiyah University of Makassar
}

\author{
${ }^{1}$ Wa Ode Rayyani, ${ }^{2}$ Ahmad Abbas, ${ }^{3}$ Hannani \\ Email : waode.rayyani@unismuh.ac.id ${ }^{1}$, ahmad.abbas@stainparepare.ac.id², hannani@iainpare.ac.id²
}

${ }^{1}$ Universitas Muhammadiyah Makassar, Indonesia

${ }^{2}$ IAIN Parepare, Sulawesi Selatan, Indonesia

\section{ABSTRACT}

The objective of this research is to describe accountability of performance integrated with the value of Islamic civilization and find the essence from framework of Islamic accountability of the organization. This research is qualitative type using interpretive spiritualism paradigm under ethnomethodology approach. The object of this research is Muhammadiyah University of Makassar and informants are people involved in making a decision in the university. The result reveals that the accountability in Muhammadiyah University of Makassar is built using religious spiritualism under a foundation of Islamic values consisting of ukhuwah and sincerity, amanah, oriented goal, effectiveness and efficiency, openness, and consistency. The further result discloses that honesty is the most reliable value to build the accountability of performance.

\author{
Keywords \\ Muhammadiyah; \\ Accountability \\ Performance; \\ Sincerity
}

\section{INTRODUCTION}

Accountability is the value of an organization in fulfilling the trust. Amanah is deemed to be holding the trust and the beginning source for achieving accountability referring to the moral responsibility to fulfill one's obligation. Besides, accountability relates to a consequence of tauhid meaning that there is a recognition and should be actualized. Tauhid is also addressed to social things called social tauhid regarded as the consequences of social work recognizing the faith of Almighty God (Rais, 1998; Dananjaya, 2014). It may affect daily activity (Fauzi, 2019). The social problems will occur when social tauhid cannot be alive. People beyond the faith must have social sensitivity and attempt to find the solution to poverty, oppression, despotism, and dictatorship. That problem is amanah to be accomplished as a way to fulfill the value of accountability.

The accountable organization can be maintaining the relationship to God (vertical) and to people (horizontal). In sharia enterprise perspective, accountability is supported by three dimensions called the trilogy of accountability that God becomes the highest principal mandating the trust, human beings are the agent, and the universe is the mandate itself (Kholmi, 2012). Each dimension has a role connected to 
another dimension. The accountability is placed in the side of the internal behavior. It can be understood as a consciousness in the form of khalifatullah fil ardh. As a result, humankind must put God as the highest principle.

Furthermore, a given obligation will be asked about the responsibility in front of God. Life in this world given by God must be asked the accountability. Humankind as khalifatullah fil ardh must put the faith and take account for the mandated obligation. Every person will be questioned as shown in Surah Al Isra verse 36.

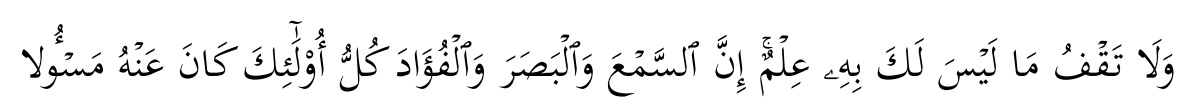

"Do not pursue that of which you have no knowledge. Indeed, The hearing, the sight and the heart-about all those (one) will be questioned" (QS. 17:36).

Accountability is an obligation in providing information from an action (Gray et al., 1987) positioning a soul or the basis of ethics (Triyuwono, 2006). Islamic University has the Islamic characteristic contained in the vision, mission, and goal. It ideally emphasizes on the Islamic values as an identity. Cost is a principle standard, or quality regarded as worthwhile or desirable (Webster, 1984). It refers to a kind of belief embraced and becomes the basis of selecting the action for being performed. In Islamic point of view, the law is the standard for regulating the action. Humankind is governed to obey the Islamic value based on Qur'an and Hadith and each person is given a high potential and correct way to undergo life (Faizi et al., 2011).

The research of Islamic civilization in Muhammadiyah organization focused on accountability is significant for being conducted. It provides substantial contributions to society through the orientation of cultural preach (Arafah et al., 2018). Remember that Muhammadiyah followers have expanded the civilization of Islamic value under the school and campus service. The education integrated with Islam provides responsible character to students (Ramadhan, 2018). Muhammadiyah University of Makassar (from now on referred to as Unismuh Makassar) is one of the largest educational organizations in East Indonesia. People provide high trust for its quality. This case is the form of amanah addressed to Muhammadiyah. Educating human being integrated with the Islamic value is the mechanism of education of Unismuh Makassar and becoming civilized society is its accountability. Understanding this case, the accountability of performance needs to be researched under the ethnomethodology approach.

Related to accountability of Muhammadiyah, as one of the largest Islamic organizations, it is no doubt that the amanah is fundamental principle, which underlies all its performances. It is undertaken as a part of organizational accountability. Its preaches through dakwah aim to spread the Islamic value. Under its article of association, Islamic sharia is enforced and maintained so as to manifest the civilized society and globally secular changes can be anticipated (Soeratno, et al., 2009).

Organizational accountability integrated with Islamic value on the educational world has been different in the business world, and Muhammadiyah, as one of the largest educational organizations seems 
to have grown to bear civilized generations(Zalik Nuryana, 2017). Under ethnomethodology approach, this research aims to describe the accountability of performance integrated with the value of Islamic civilization in Unismuh Makassar and find the framework to build the design of quantitative analysis as a part of future research. Indexicality and reflexivity from decision-makers in the University are interesting to be elaborated so that this research can find the essence of Islamic accountability of organization.

The result of this research contributes to the literature regarding accountability and performance in the body of Islamic organizations. It may disclose the differences in value of accountability owned by Islamic business organizations. As demonstrated by Amerieska et al. (2012) in BMT that accountability is not suitable with sharia enterprise theory. In the business world, although its organization is integrated with the Islamic value, God will not be the only responsibility center. The capital owner has been the first center and everything is addressed in advance to him as principal. In another finding, Islamic organizations should contain values gaining the falah as found in Dompet Duafa. Those are obedience, fairness, caring, and welfare leading the management to maintain amanah and be accountable (Zulfayani, 2019). The manifestation of its accountability is spirit and social.

This research is a qualitative type designed using interpretive-spiritualism paradigm under ethnomethodology approach. In the paradigm, a text is interpreted through holy book which develops to understand the social (Triyuwono et al., 2016). The context of this research is set using the presentation of religious spiritualism values and to be the foundation to understand the finding. The focus of this research is to disclose the indexicality and understand individual behavior in a social environment (Coulon, 1995; Ludigdo, 2007; Affandi, 2014). Daily activity is the characteristic of ethnomethodology. Every individual becoming a member of the community of acting together to form the social order is nature of this research.

The object of this research is Unismuh Makassar. Under the ethnomethodology approach, local wisdom and religion are the sources of thought and behavior in making a decision and achieving the goal (Triyuwono, et al., 2016). The key person consists of Rector, Vice-Rector 1, Vice-Rector 4, Dean, and Chief Public Relations. Whole informants are relevant to the need for this research because they are people involved in making a decision in the university. The decision making from the prominent figures bases on the custom and becomes the foundation to obtain the information. 
Table 1. Informant of research

\begin{tabular}{cc}
\hline Informant & Position \\
\hline Prof H. Irwan Akib M.Pd & Rector \\
H. Abd Rahman Rahim & Vice-Rector 1 \\
Dr. H. Abdul Rahim Nanda & Vice-Rector 4 \\
Drs H. Sultan Sarda MM & Vice Dean 1 of Economic Faculty \\
Drs Abdul Wahab Saleh & Chief Public Relation \\
\hline
\end{tabular}

Data are analyzed using the interactive model developed by Miles and Huberman (1984) that the process of data starts from the data collection through observation, in-depth interview using a recording device and documentation, Some field notes and transcript of conversation are documented during the process of collecting data so that the result of data presented in this research is more accurate. Having obtained data, this research attempts to find the meaning of indexicality and reflexivity through tafakkur and dhikr (Triyuwono, 2015). Contemplation through the subconscious is undertaken to confirm the understanding of the reality in this research (Murphy, 2006; Newberg and Waldman, 2009).

Indexicality and reflexivity are essential concepts of ethnomethodology approach (Coulon, 2008; Denzin and Lincoln, 2009). Indexicality is a set of explicit information shown in an indexed sentence (Gamar and Djamhuri, 2015) obtained from actors in understanding their role, and otherwise, reflexivity is a set of implicit information outside the boundary of actors' consciousness.

\section{DISCUSSION}

\section{Accountability of Performance in Unismuh Makassar}

Muhammadiyah is an organization pioneered by KH Ahmad Dahlan. The spirit of him is strongly embedded in creating educational organization. "Talk less, do more" may be a phrase describing the performance in Unismuh Makassar as an educational organization under Muhammadiyah. It has acted to preach reform to its members in line with the objective of Muhammadiyah enforcing and upholding Islamic principles. All managements on the campus, both lecturers and employees are aware of the principle and always overcome the responsibility in line with social tauhid. Vice-Rector 1 states that:

".....to measure good performance, the campus can lead the goal of struggle of Muhammadiyah life. It can be achieved, see how far this campus achieve the goal as an educational institution" (Abd Rahim Rahim).

The quote above implies the existence of campus in supporting the goal of Muhammadiyah. Unismuh Makassar educates its students in line with Islamic preach. It manifests the accountability by actualizing the characteristic of Muhammadiyah as the Islamic organization to their thought. In addition, Vice-Rector 4 states that: 
".....the performance could be understood that it builds the force to do teamwork in the same pattern bearing good productivity in accordance with the goal of organization. My daily activity concretely shows the work which should be performed, successful, well-planned, effective, efficient, and measurable actions. Those are the benchmark in the success of a program" (Abdul Rahim Nanda).

For achieving the goal, the basic values belong to Unismuh Makkassar including ukhuwah and sincerity, amanah, oriented goal, effectiveness and efficiency, openness, and consistent teamwork. Ukhuwah and sincerity are the basic value owned by Unismuh Makassar to achieve the performance. As stated in the following interview:

“.... Unismuh develops the basic values in the performance. First, the value is ukhuwah and sincerity, second is professionalism and independence. Third, efficiency. Fourth, Opennes, which generates good accountability" (Abdul Rahim Nanda).

The value of $u k h u w a h$ is underlined in above statement. Ukhuwah in Unismuh Makassar can be seen from a brotherhood between lecturers and employees under the platform of Muhammadiyah integrating them into a very strong emotional relationship. Both have same paradigm about the obligation and strong relationship to work. Each job is accomplished professionally and independently. They are accountable with the rights, duty as well as the kind of policy related to campus activity. They hold the value of ukhuwah as disclosed in Al-Hujurat Verse 10.

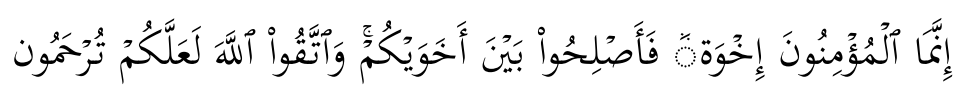

"The believers are but brother, so make a settlement between your brothers. And fear Allah that you may receive mercy" (QS.49:10).

The understanding of the value of Muhammadiyah through ukhuwah encourages the spirit to be one. As a result, the values owned by Unismuh Makassar until now derive from Islamic civilization of Muhammadiyah and ukhuwah is the value in the first line. The reflection of accountability of performance in Unismuh Makassar bases on the spiritual-religious and provides two elements, namely collective and individual accountability. Both form the character of the campus. 
The following scheme is shown in Figure 1.

Figure 1. Accountability Integrated with the Values of Muhammadiyah

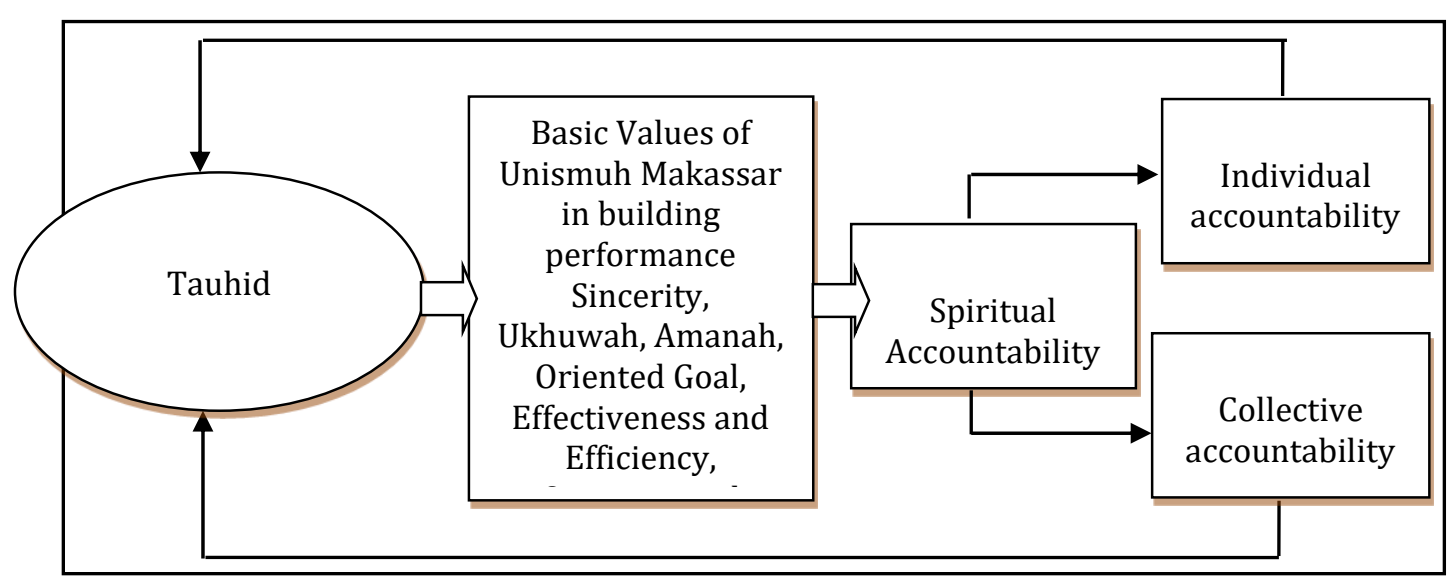

Figure 1 describes some fundamental things. Tauhid as foundation to bear the accountability. Unismuh Makassar is an educational organization integrated with Islam. God is basic orientation and principal in the practice of performance accountability. All activities in Unismuh Makassar provide the lofty and sublime values, namely amanah, oriented goal, effectiveness and efficiency, openness, and consistency. These lead the spiritual value both individual and collective accountability. Both manifested into human resources will return to God as a report of accountability. Related to individual accountability, honesty will be reflected in the personality of human resources of Unismuh Makassar. Attitude and behavior have led the high dedication towards his performance and motivated people in the surroundings to behave independently. Strengthening grades is needed to design universities and their students. students who internalize Islamic values will have a good character(Nuryana, Rahman, \& Setiawan, 2019).

The reflexivity of behaviors owned by management of Unismuh Makaassar can be understood that the work is not only to fulfill the material need, but also the spiritual need. By embracing the sincerity, the heart will be satisfied and managements can be accountable to perform the duty. There is no responsibility without amanah, and there is not amanah without sincerity. They further behave positively into the working environment and they behave loyally to the campus. It can be shown that they have the moving life about dozens of years and still commit the mandate of respective positions. The distressed life to develop the Unismuh Makassar has been experienced and the commitment is a manifestation of love and affection to the organization. That is why, amanah refers to trust among them and between God and individual as they hold the belief of An Nisa verse 58 .

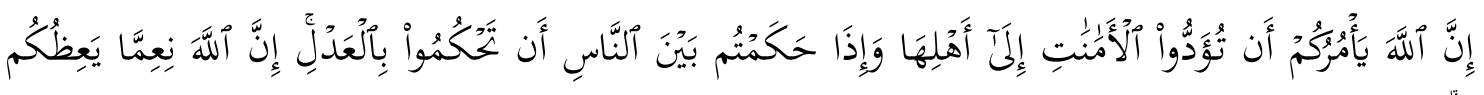

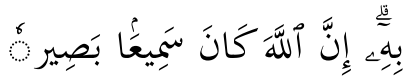


"Indeed, Allah commands you to render trusts to whom they are due and when you judge between people to judge with justice. Excellent is that which Allah instructs you. Indeed, Allah is ever Hearing and Seeing" (QS. 4:58).

Furthermore, the value of Islamic civilization on the campus creates strong atmosphere coming from the value of Muhammadiyah. When entering the campus, the existence of the mosque was built in the right of entrance gate of the campus. The religious atmosphere was felt to the heart leading people to remember Almighty God. Each banner starts with the greeting of Basmalah (in the name of God, the Most Gracious, the Most Merciful), implying that each activity starts with Basmalah. Picture 1 is a proof showing the integration with Islamic value in the campus area. On the other hand, when the calling of Adzan to do the pray began, all activities did break and people went the mosque, including the activity of lunch in the cafeteria in which food and drink were closed for thirty minutes. When entering the area of Cafetaria, there was a slogan of Cheap and Blessing implying that the food and drink are not only cheap but Insha Allah those will bring kindness to the body and soul.

The Islamic value is so reflected in the campus coming from manifestation of tauhid and faith. Each word should be line with faith. God has always been the main pointer in accomplishing the duty on the campus. Then, individual accountability emerges and feels that God will still see what we have carried out because He always watches us. An accountable individual brings organization into the visible realm that $\mathrm{He}$ has predetermined in the spiritual realm. If an individual maintains a great value of accountability in the performance, organization will reach the goal.

Figure 2. The Reflection of Islamic Value

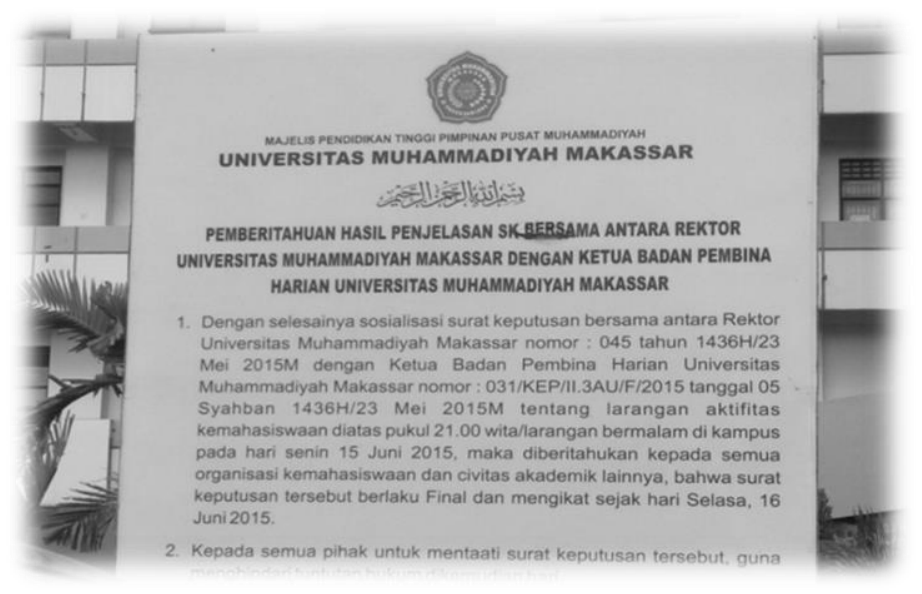

\section{Sincerity: Strong Spirit in Leading the Influence of Accountability on Performance}

The foundation of accountability in the world holds spiritual and moral value. It will relate to the report addressed to the organization and God. The form of responsibility refers to obedience-based on the sincerity and the essence of spirit of Muhammadiyah. When interviewing Chief Public Relation of Unismuh, he states that: 
"As a Muhammadiyah follower, we should be thankful what He has been given to us. Alhamdulillah we can be steward in Muhammadiyah. For the performance, I have accountability for the future of this campus" (Abdul Wahab Saleh).

When interviewing the informant, it sounds soulful. He felt thankful to be a part to develop the campus. Salary is not a demand to more perform. His spirit of leading the university better is amanah to be done. The further statement comes from Vice Dean 1 of Economic Faculty.

"They also make a living not called as the salary, we are here also making our family live. We work here due to worship. Well, although the salary provided on this campus is low, people develop this campus because of spirit of faith, sincerity. KH Ahmad Dahlan has message that "make Muhammadiyah live, do not make a living in Muhammadiyah" (Sultan Sarda).

The meaning of indexicality related to above statement is sincerity revealing that personal responsibility is reflected in daily performance. The performance is an amanah to be done and its result is for worship. The salary is an acknowledge not an extrinsic factor to increase the performance. People are sincere to work in the name of lillahi ta'ala because they regard it as worship addressed to God, not to eager much salary. Gratitude to Almighty God for what has been given is the behavior of life in Unismuh Makassar in ending the job. It encouraging Muhammadiyah can grow and make the progress continually.

Sincerity to hold amanah is the value embracing of performance accountability in the spiritual dimension in Unismuh Makassar. Its executive officers have high performances, although their salary is perceived low compared to other institutions. They regard it not as a primary priority, but sincerity is the beginning capital to work. They are forceful to hold the message of $\mathrm{KH}$ Ahmad Dahlan that "make Muhammadiyah live, do not make a living in Muhammadiyah." As a result, sincerity is a strong spirit in the soul of management in the Unismuh Makassar. Performance is deemed to be the completion of obligation given by organization because of the mandate of God. It has been influenced by accountability meaning that the value of accountability should in advance belong to each person before carrying out mandated obligation. The increase of performance in Unismuh Makassar was influenced by organizational accountability dimensioned by individual and collective accountability moderated by sincerity from the executive officer. In other words, sincerity strengthened the spirit of organizational accountability on high performance.

\section{CONCLUSION}

God has reminded that people will be called to account for every major and minor action that they did in the world. Not only individual but organizational performance also will be asked its accountability. The accountability of performance in Unismuh Makassar derives from the consciousness that performance in the organization is collective accountability. Each deed undertaken in accomplishing the job description has social and spiritual value. Holding amanah from organization is like holding the 
mandate of God. Unlike business organization, Unismuh Makassar puts amanah between God and its management.

There are some fundamental things concluded in this research. First, the accountability of performance in Unismuh Makassar bases on the values of Muhammadiyah sourced from Qur'an. It becomes the manifestation of Tauhid to God. Unismuh Makassar packages its education through the values including ukhuwah and sincerity, amanah, oriented goal, effectiveness and efficiency, openness, and consistency. Its law and regulation are enforced and integrated with the sharia value leading its generation to grow and develop to be civilized mankind. The creation of best generations of khayr alummah is its outcome leading its followers to join the life what is right and forbid what is wrong. Second, Unismuh Makassar grows and develops through the spirit of sincerity as highly strong value to build the accountability of performance. Sincerity moderates the relationship between organizational accountability and performance.

Overall, the reflection of accountability divided into collective and individual accountability in Unismuh Makassar bases on religious spiritualism. Both are addressed to lead the performance. The result of this research provides a design to do additional research. As the suggestion for future research, the indicators of model described in this research become the beginning step to design the quantitative approach because the relationship between Islamic value and accountability of performance is feasible to be tested.

\section{REFERENCES}

Al-Qur'an and al-Karim

Affandi, A. (2014). Makna Pembiayaan Salam Perspektif Perbankan Syariah dan Petani di Probolinggo. Jurnal Ilmiah Mahasiswa Fakultas Ekonomi dan Bisnis Universitas Brawijaya, Volume 2, Number 2.

Amerieska, S., G., Irianto, S. P. Affandy. (2012). Akuntabilitas pada Baitul Maal Wat Tamwil Ditinjau dari Perspektif Sharia Enterprise Theory. Jurnal Ekonomi dan Keuangan Islam, Volume 2, Number 1, pp. 27-39.

Arafah, M., Budira, and Suarni. (2018). Gerakan Dakwah Kultural dalam Mewujudkan Masyarakat Berperadaban dalam Perspektif Muhammadiyah. In the $7^{\text {th }}$ National Conference Asosiasi Program Pascasarjana Perguruan Tinggi Muhammadiyah 'Aisyiyah (APPPTMA). http://asosiasipascaptm.or.id/images/phocadownload/KNPPPTN_ke 7/PROSIDING_APPPTM_7/318.pdf.

Coulon, A. (1995). Ethnometodology. Sage Publications, Inc. SAGE Research Methods.

Dananjaya, H. (2014). Membumikan Tauhid Sosial Ala Amien Rais. http://sangpencerah.id/2014/04/membumikan-tauhid-sosial-ala-amien-rais.html. Accessed April 2016.

Denzin, N.K., and Lincoln, Y. S. (2009). Handbook of Qualitative Research (translation edition). Yogyakarta: Pustaka Pelajar.

Faizi, W.N, A.F, Shakil, S.H, Akhtar, and F.A, Lodhi. (2011). The Role of Different Factors in the Promotion of Islamic Values among the Students of Secondary Level In Karachi, Pakistan”. International Journal of Academic Research in Business and Social Sciences, 1(3): 220-232. 
Fauzi, Niki Alma Febriana (2019). Muhammadiyah's New Fiqh Reasoning : Constructing a Holistic Islamic Law Paradigm (Nalar Fikih Baru Muhammadiyah: Membangun Paradigma Hukum Islam yang Holistik. Afkaruna: Indonesian Interdisciplinary Journal of Islamic Studies, Volume 15, Number 1 (2019), pp. 32-54.

Gamar, N and Djamhuri, A. (2015). Auditor Internal sebagai "Dokter" Fraud di Pemerintah Daerah. Jurnal Akuntansi Multiparadigma (JAMAL), Volume 6, Number 1, pp. 107-123.

Gray, R., Owen, D., \& Maunders, K. (1987). Corporate Social Reporting: Accounting and Accountability. London: Prentice Hall.

Kholmi, M. (2012). Akuntabilitas dan Pembentukan Perilaku Amanah. Jurnal Studi Ekonomi Islam, Volume 15, Number 1, pp. 63-72.

Ludigdo, U. (2007). Paradoks Etika Akuntan. Yogyakarta: Pustaka Pelajar.

Miles, M.B and Huberman, A.M. (1984). Analisis Data Kualitatif. Terjemahan dari Tjetjep Rohendi Rohidi. Jakarta: Universitas Indonesia.

Murphy, J. (2006). The Power of Your Subconscious Mind. London: Pocket Books.

Newberg, A. and Waldman, M.R. 2009. How God Changes Your Brain. New York: Ballantine Books.

Nuryana, Z., Rahman, A., \& Setiawan, F. (2019). The Curriculum Model of Study Program-based Muhammadiyah Form of Cadre. Proceedings of the First International Conference on Progressive Civil Society (ICONPROCS 2019), 317(IConProCS), 208-211. https://doi.org/10.2991/iconprocs$\underline{19.2019 .44}$

Rais, M.A (1998). Tauhid Sosial - Formula Menggempur Kesenjangan. Mizan.

Ramadhan, D. (2018). Educational Values in Saprahan Tradition in the Malay Community of Sambas District. KHATULISTIWA: Journal of Islamic Studies, Volume, 8, Number 1, pp. 29-39.

Soeratno, S.C, et al. (2009). Muhammadiyah sebagai Gerakan Seni dan Budaya: suatu Warisan Intelektual yang Terlupakan, Cetakan 1. Yogyakarta: Pustaka Pelajar.

Triyuwono, I. (2006). Perspektif, Metodologi dan Teori Akuntansi Syariah. Edisi Satu. Jakarta: PT Rajagrafindo Persada.

.I, A., D. Mulawarman, A. Djamhuri., D. Prawironregoro. (2016). Filsafat Ilmu Akuntansi. Jakarta: Mitra Wacana Media.

(2015). Spiritualitas Akuntansi Malangan: Salam Satu Jiwa dan Konsep Kinerja Klub Sepakbola. Jurnal Akuntansi Multiparadigma (JAMAL ), Volume 6, Number 2, pp. 290-303.

Webster, A. (1984). Introduction to the Sociology of Development. Cambridge: Macmillan.

Zulfayani, A. (2019). Dual Accoountability: Manifestasi Akuntabilitas Dompet Dhuafa Sulawesi Selatan. ACCOUNTIA: Accounting, Trusted, inspiring, Authentic Journal, Volume 3, Number 1, pp. 319330.

Zalik Nuryana. (2017). Revitalisasi Pendidikan al Islam dan Kemuhammadiyahan pada Perguruan Muhammadiyah. TAMADDUN, 1, 1-11. 